\title{
Selection of putative Terra Maranhão plantain cultivar mutants obtained by gamma radiation
}

\author{
R.V. Reis ${ }^{1}$, E.P. Amorim², C.A.S. Ledo ${ }^{2}$, R.K.N. Pestana ${ }^{1}$, Z.S. Gonçalves ${ }^{3}$ \\ and A. Borém ${ }^{1}$ \\ ${ }^{1}$ Universidade Federal de Viçosa, Viçosa, MG, Brasil \\ ${ }^{2}$ Embrapa Mandioca e Fruticultura, Cruz das Almas, BA, Brasil \\ ${ }^{3}$ Universidade Federal do Recôncavo da Bahia, Cruz das Almas, BA, Brasil \\ Corresponding author: R.V. Reis \\ E-mail: ronaldo.viana@ufv.br \\ Genet. Mol. Res. 14 (2): 4687-4695 (2015) \\ Received August 1, 2014 \\ Accepted February 27, 2015 \\ Published May 11, 2015 \\ DOI http://dx.doi.org/10.4238/2015.May.11.1
}

\begin{abstract}
The aim of this study was to select putative Terra Maranhão plantain cultivar mutants obtained by gamma radiation, with good agronomic traits and short height. A total of 315 buds were irradiated in vitro with gamma rays in doses of 20 Gy and were subcultivated and evaluated in the field over 2 production cycles. The clones were evaluated to select the best $10 \%$ of the plants. Cultivation was undertaken at a spacing of $3 \times 4 \mathrm{~m}$, and fertilization was carried out according to the technical recommendations for the crop. A total of 111 irradiated plants and 41 controls were evaluated in the field. Among the irradiated plants selected, genotypes that exhibited reduced height were observed. The genotypes Irra 04, Irra 13, Irra 19, and Irra 21 exhibited a height of $3.6 \mathrm{~m}$, which was below the mean value of the controls selected. Other irradiated genotypes selected such as Irra 14 and Irra 16, with a height of $3.65 \mathrm{~m}$, are promising because, in addition to reduced height, they exhibited good bunch weight and shorter period to flowering in relation to the mean value of the controls, which is a
\end{abstract}


significant factor for the next stages in breeding. These results confirm the possibility of inducing mutations in Terra type banana plants to obtain desirable agronomic traits and short height.

Key words: Musa spp; Short plant stature; Selection of mutants

\section{INTRODUCTION}

With an approximate production of 6.87 million tons in 2012 and an area cultivated of approximately 526,000 hectares (IBGE, 2013), Brazil stands out as the fifth banana producer worldwide, and northeastern Brazil is responsible for $41 \%$ of the national production (IBGE, 2013).

Nevertheless, banana growers in the country face serious problems in the production and post-harvest phases, and one of the factors that leads to losses is the elevated height of the main commercial cultivars. Tall plants hinder bunch harvest (Ledo et al., 1997), leading to a high rate of toppling. In contrast, short plants, in addition to facilitating harvest, allow denser planting and, consequently, greater yield per unit of area (Alves and Lima, 2000).

Bananas and plantains are among the most important food crops in the world and are grown in more than 126 tropical countries, mostly by small farmers (FAO, 2013). The main representative of the plantain subgroup in Brazil is the Terra Maranhão cultivar (AAB triploid). This cultivar is susceptible to Black Sigatoka and is quite tall, traits that hinder its use as a major crop (Silva et al., 2002).

A strategy to solve this problem is the development of new cultivars from crosses, followed by selection in progenies (Silva et al., 2002; Donato et al., 2006). However, in the case of the banana plant, characteristics, such as non-viable pollen grains, female sterility, and reduced number of seeds (De Guzman et al., 1982; Shepherd, 1987), hinder traditional breeding methods.

Therefore, in cases where the natural genetic variability is limited or there are difficulties related to the applications of traditional breeding methods, inducing mutations is tool that may help to overcome these barriers (Pestana et al., 2010).

Mutations are defined as inheritable alterations in the DNA sequence that are not derived from gene recombination and/or genetic segregation, and they represent the genetic basis of variations (Niwa, 2006). These mutations are important in genetic breeding programs because they produce new allelic forms that may confer new agronomic traits, increasing the genetic resources that are available for breeding.

The induction of mutations by gamma rays and in vitro propagation techniques constitute highly useful tools in breeding programs to reduce the height of the banana plant. This mutation technique is recommended for elite cultivars and also to obtain resistance to diseases or agronomic traits that are controlled by 1 or few genes, because it preserves the other traits of the original phenotype (Bermudez-Caraballoso et al., 2010).

Therefore, the application of mutagenesis associated with the use of other in vitro technologies constitutes a promising alternative for genetic breeding programs of this species with a view of reducing plant height, increasing genetic variability, and reducing the time to the selection of mutants with potential for introduction as a new cultivar. In this context, the aim of this study was to evaluate the genetic variability and select genotypes with good agronomic traits and reduced height in a set of putative mutants of Terra Maranhão plantains that were obtained by gamma radiation. 


\section{MATERIAL AND METHODS}

\section{Gamma irradiation of in vitro buds}

A total of 315 in vitro buds were irradiated using $\left[{ }^{60} \mathrm{Co}\right]$ in the Center for Nuclear Energy in Agriculture (CENA), in partnership with the Universidade de São Paulo (USP). The dose used was $20 \mathrm{~Gy}$, which was previously identified in the sensitivity test (Pestana et al., 2010). Fifty buds were used as controls, which were also sent to CENA/USP; however, they were not exposed to $\left[{ }^{60} \mathrm{Co}\right]$.

The irradiated buds were transferred to a basic Murashige and Skoog (1962) (MS) culture medium that was solidified with $2.2 \mathrm{~g} / \mathrm{L}$ Phytagel and supplemented with $30 \mathrm{~g}$ sucrose and $3.0 \mathrm{mg} / \mathrm{L}$ benzylaminopurine, $\mathrm{pH}$ 5.8. Afterwards, plantlets were kept in a growth chamber at a controlled temperature of $27^{\circ} \pm 2^{\circ} \mathrm{C}$ and 16 -h fluorescent light photoperiod and $8 \mathrm{~h}$ darkness. Plantlets were subjected to 4 subcultures performed at 30-day intervals.

After the subcultures, the plants were rooted in MS medium with the addition of 0.25 $\mathrm{mg} / \mathrm{L}$ naphthaleneacetic acid and $8 \mathrm{~g} / \mathrm{L}$ agar, $\mathrm{pH} 5.8$, and then placed in a growth chamber with 16-h fluorescent light photoperiod at luminous intensity of $40 \mu \mathrm{mol} \cdot \mathrm{m}^{-2} \cdot \mathrm{s}^{-1}$ and $8 \mathrm{~h}$ darkness at a temperature of $26^{\circ} \pm 2^{\circ} \mathrm{C}$, where they remained for a period of 35-40 days.

The already rooted plants were taken to a greenhouse where they were acclimatized in root plugs containing the commercial substrate Plantmax (composed of processed wood bark, expanded vermiculite, granulated carbon, and processed peat enriched with macro- and micronutrients) and Sombrite shade screening that controls 50\% of the luminosity, and irrigation was performed by an automatic spraying system.

\section{Field evaluation of putative mutants}

The experiment was carried out in the experimental field of Embrapa Mandioca e Fruticultura to select shorter banana clones of the Terra variety that had good agronomic traits. The experiment was established mainly to select approximately the best $10 \%$ of the plants. Planting was made at a spacing of $3 \times 4 \mathrm{~m}$, and fertilization was performed according to the technical recommendations for the crop. The irradiated and non-irradiated (control) plants that completed 2 production cycles in the field were evaluated and selected.

The following agronomic traits were evaluated during the flowering period in 2 production cycles: number of days from planting to flowering, pseudostem diameter $(\mathrm{cm})$, plant height $(\mathrm{m})$, number of leaves at flowering, and number of suckers. The following agronomic traits were evaluated at the harvest of the bunches: number of days from planting to harvest, number of days from flowering to harvest, bunch weight $(\mathrm{kg})$, hand weight $(\mathrm{kg})$, number of fruits, average weight of the fruits $(\mathrm{g})$, length of fruits from the second hand $(\mathrm{cm})$, length of fruits from the next-to-last hand $(\mathrm{cm})$, diameter of fruits from the second hand $(\mathrm{mm})$, diameter of fruits from the next-to-last hand ( $\mathrm{mm}$ ), number of hands, number of live leaves at harvest, length of the peduncle $(\mathrm{cm})$, diameter of the peduncle $(\mathrm{cm})$, length of the fruit stalk $(\mathrm{cm})$, and diameter of the fruit stalk $(\mathrm{cm})$.

\section{Data analysis}

Initially, the genetic diversity of the 111 putative mutants was evaluated using 
21 agronomic traits; the genetic distance matrix was obtained using the Genes computer application (Cruz, 2006). Cluster analysis was performed by the unweighted pair-group method with arithmetic mean (UPGMA) using the Mega-4.1 software (Tamura et al., 2007) and based on the mean Euclidean distance matrix. The cophenetic correlation coefficient between the genetic distance matrix and the cophenetic values matrix was calculated using the R software (R Development Core Team, 2010) to verify the consistency of the clusters.

To select the approximately $10 \%$ shortest plants, the methodology proposed by Resende (2005) was used. Initially, individual plants of the population were classified according to the traits that were considered to be important in selection, such as shorter plant height, fewer days from planting to flowering, and greater bunch weight. The data obtained for these traits were ranked by increasing order for plant height and number of days to bunch emergence) and decreasing order for bunch weight, obtaining the classification number of each plant. Afterwards, a selection index that was based on the ranking of each genotype was calculated by multiplying the classification number of each plant by the weight corresponding to each trait. For plant height, a weight of 6 was given because it was considered to be the most relevant trait; a weight of 2 was given to the number of days from planting to flowering and bunch weight. At the end of this process, a final score was obtained for each plant using the following selection index: $y=[0.6 \times$ (height classification $)+0.2 \times$ (bunch emergence classification) $+0.2 \times$ (bunch weight classification)]. In each cycle, the final score was placed in increasing order, obtaining the final classification.

\section{RESULTS AND DISCUSSION}

Determining the genetic diversity among individuals is an important and decisive point for clustering and evaluating the genetic diversity within and among populations (Kosman and Leonard, 2005). In this context, the genetic diversity of 111 putative mutants was analyzed using 21 quantitative traits through the mean Euclidean distance, and a dendrogram was obtained using the UPGMA method (Figure 1).

The distance between the putative mutants ranged from 0.086 to 0.555 , with a mean distance of 0.256 . The cophenetic correlation coefficient of 0.778 was considered to be adequate in these studies (Vaz Patto et al., 2004; Pestana et al., 2011). The closest genotypes were Irra 78 and Irra 93, with a genetic distance of 0.086 , and the most distant genotypes were Irra 48 and Irra 54, with a genetic distance of 0.555 .

Our results confirm the variability among the putative mutants, which may be exploited. Additionally, this variability is mainly due to the effect of gamma radiation. Somaclonal variation and subcultures do not normally lead to genetic alterations in a large number of clones from the same genotype.

A similar result was observed in the study that was carried out by Pestana et al. (2011). The authors, working with Prata type banana, identified genetic distances between the putative mutants that ranged from 0.26 to 0.64 and had a mean distance of 0.459 , and the cophenetic correlation coefficient was 0.7669 . The nearest putative mutants were Pacovan 65 and Pacovan 67, with a genetic distance of 0.26 , and the most diverse genotypes were Pacovan 26 and Pacovan 2, with a genetic distance of 0.64 . 


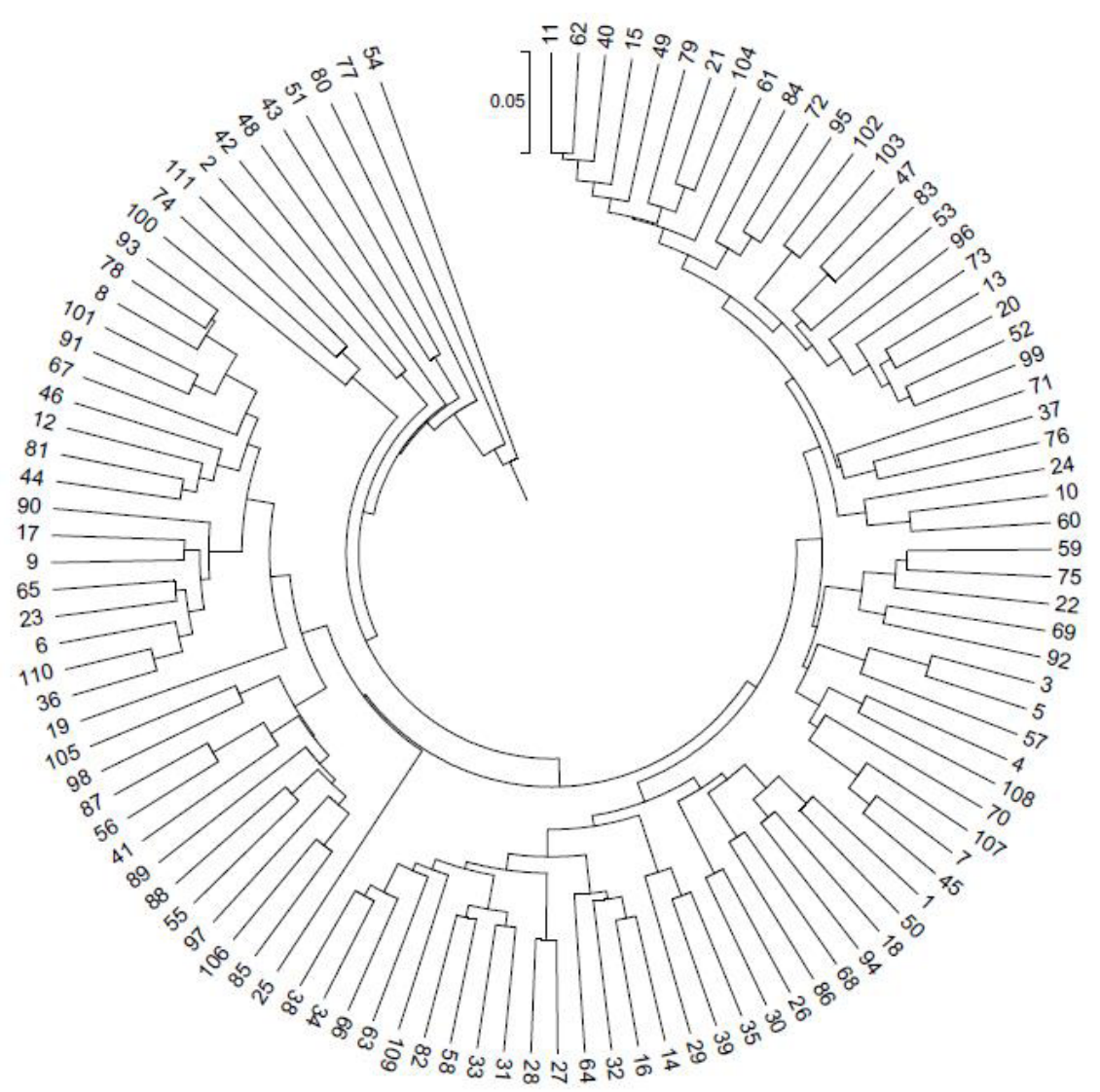

Figure 1. Dendrogram obtained by 21 quantitative variables and genetic distance matrix of 111 putative mutants of Terra Maranhão plantain cultivar induced by gamma radiation based on the mean Euclidean distance.

The relative contribution of the agronomic traits to the diversity of the putative mutants of the Terra Maranhão plantain cultivar is shown in Table 1. The variable that most contributed to the genetic diversity was the number of days from planting to harvest, which contributed to $36 \%$ of the diversity, followed by the variable of number of days from planting to flowering $(28 \%)$. The production traits average weight of the fruits and bunch weight accounted for 21 and $7 \%$ of relative contribution to genetic diversity, respectively (Table 1).

With induced mutations, the putative mutants presented distinct behaviors that were more evident when evaluating the production cycles. This confirmed that there was variability among the genotypes studied and that there were conditions that allowed the selection of putative mutants that exhibited an early cycle and greater yield.

The variables of number of fruits, bunch weight, average weight of the fruits, and plant height of the irradiated and control plants in reference to the 2 production cycles are shown in Table 2. When the mean values were analyzed, the irradiated plants and the controls showed similar values for the number of days from planting to harvest, number of days from planting to flowering, and number of days from flowering to harvest traits (Table 2). 
Table 1. Relative contribution of the agronomic traits to divergence of putative mutants of Terra Maranhão plantain cultivar obtained by gamma radiation in the first and second production cycles evaluated by the Singh (1981) method.

\begin{tabular}{lrr}
\hline Variables & \multicolumn{1}{c}{$\mathrm{S} . \mathrm{j}$} & Value $\%$ \\
\hline NDPF & 25656234 & 28.8268 \\
NDFH & 2804094 & 3.1506 \\
NDPH & 32405948 & 36.4106 \\
PH & 759.278 & 0.0009 \\
PD & 78249.43 & 0.0879 \\
NLF & 29330 & 0.033 \\
NS & 35342 & 0.0397 \\
LFS & 23744 & 0.0267 \\
DFS & 1761390 & 1.9791 \\
NH & 221062.2 & 0.2484 \\
NF & 22640 & 0.0254 \\
BW & 6368264 & 7.1552 \\
HW & 269971.6 & 0.3033 \\
AWF & 254102 & 0.2855 \\
LFSH & 18912263 & 21.2494 \\
LFNLH & 75126.98 & 0.0844 \\
DFSH & 65520.5 & 0.0736 \\
DFNLH & 3782.76 & 0.0043 \\
LP & 2832.56 & 0.0032 \\
DP & 10490.38 & 0.0118 \\
\hline S.j & &
\end{tabular}

$\mathrm{S} . j=$ relative importance of characters; $\mathrm{NDPF}=$ number of days from planting to flowering; $\mathrm{NDFH}=$ number of days from flowering to harvest; $\mathrm{NDPH}=$ number of days from planting to harvest; $\mathrm{PD}=$ pseudostem diameter $(\mathrm{cm}) ; \mathrm{PH}=$ plant height (m); NLF = number of leaves at flowering; NS = number of suckers; LFS = length of the fruit stalk $(\mathrm{cm})$; $\mathrm{DFS}=$ diameter of the fruit stalk $(\mathrm{cm}) ; \mathrm{NH}=$ number of hands; $\mathrm{NF}=$ number of fruits; $\mathrm{BW}$ : bunch weight $(\mathrm{kg}) ; \mathrm{HW}=$ hand weight $(\mathrm{kg}) ; \mathrm{AWF}=$ average weight of the fruits $(\mathrm{g}) ; \mathrm{LFSH}=$ length of fruits from the second hand $(\mathrm{cm}) ; \mathrm{LFNLH}$ $=$ length of fruits from the next-to-the-last hand $(\mathrm{cm}) ; \mathrm{DFSH}=$ diameter of fruits from the second hand (mm); DFNLH $=$ diameter of fruits from the next-to-the-last hand $(\mathrm{mm}) ; \mathrm{LP}=$ length of the peduncle; $\mathrm{DP}=$ diameter of the peduncle.

Table 2. Mean values for the agronomic traits of the putative mutants of Terra Maranhão plantain cultivar and of the controls in two production cycles.

\begin{tabular}{lrr}
\hline Variables & Irradiated & Controls \\
\hline NDPF & 465.9 & 442.33 \\
NDFH & 104.79 & 105.12 \\
NDPH & 571.06 & 547.33 \\
PH & 3.97 & 3.74 \\
PD & 25.09 & 25.28 \\
NLF & 10.18 & 10.16 \\
NS & 8.34 & 8.50 \\
LFS & 48.27 & 44.73 \\
DFS & 6.02 & 5.76 \\
NH & 9.75 & 9.66 \\
NF & 142.27 & 138.33 \\
BW & 2.92 & 22.63 \\
HW & 24.84 & 26.06 \\
AWF & 175.12 & 167.51 \\
LFSH & 20.23 & 20.83 \\
LFNLH & 17.69 & 17.71 \\
DFSH & 3.99 & 3.86 \\
DFNLH & 3.39 & 3.36 \\
LP & 4.96 & 5.45 \\
DP & 1.25 & 1.25 \\
\hline
\end{tabular}

For abbreviations, see legend to Table 1.

Analysis of the individual performance of each genotype revealed that some genotypes selected in the second production cycle showed improved traits compared to the controls relative to the most relevant agronomic traits, such as bunch weight, number of days from plant- 
ing to harvest, and plant height. Therefore, it is possible to affirm that selection seems quite promising. Bermúdez et al. (2000), working with mutants from the FHIA-21 cultivar, observed a variation of $4.8 \%$ in the first cycle and the most altered traits were plant height and number of fruits per bunch. Similar observations were made in this study, in which some irradiated genotypes showed significant differences for the traits under study compared to the controls.

Jamaluddin (1994) used radiation doses that ranged from 10 to $60 \mathrm{~Gy}$ and/or ethylmethanesulfonate to induce mutations in banana in vitro. This led to the selection of earlier clones of Grande Naine (Fatom-1) and Pisang Rastali (AAB Silk).

Bunch weight, hand weight, and average weight of fruits exhibited higher values in the selected plants than in the controls in the first cycle; however, these differences were not significant (Table 3). Nevertheless, in the second cycle, the values for these variables were slightly higher in the controls than in the irradiated plants, and plant height practically remained the same. In addition, there was a decrease of $49 \mathrm{~cm}$ in the mean value of the selected plants from one cycle to the other (Table 3 ).

Table 3. Treatment x cycle interaction of putative mutants selected of Terra Maranhão plantain cultivar and the
controls evaluated in two production cycles.
\begin{tabular}{lrrrrr}
\hline Variables & \multicolumn{2}{c}{ Cycle 1 } & \multicolumn{2}{c}{ Cycle 2 } \\
\cline { 2 - 5 } & Selected & Controls & 22.63 & Selected & Controls \\
\hline BW & 32.42 & 29.10 & 21.44 & 24.76 \\
HW & 30.12 & 158.23 & 19.56 & 23.03 \\
AWF & 189.51 & 3.79 & 3.73 & 176.8 \\
PH & 4.21 & & 3.70 \\
\hline
\end{tabular}

$\mathrm{BW}=$ bunch weight $(\mathrm{kg}) ; \mathrm{HW}=$ hand weight $(\mathrm{kg}) ; \mathrm{AWF}=$ average weight of the fruits $(\mathrm{g}) ; \mathrm{PH}=$ plant height $(\mathrm{m})$.

Twenty-two irradiated genotypes were selected based on the index that was weighted according to the importance of plant height, number of days from planting to harvest, and bunch weight. Among the irradiated plants that were selected, some genotypes showed reduced height (Figure 2).

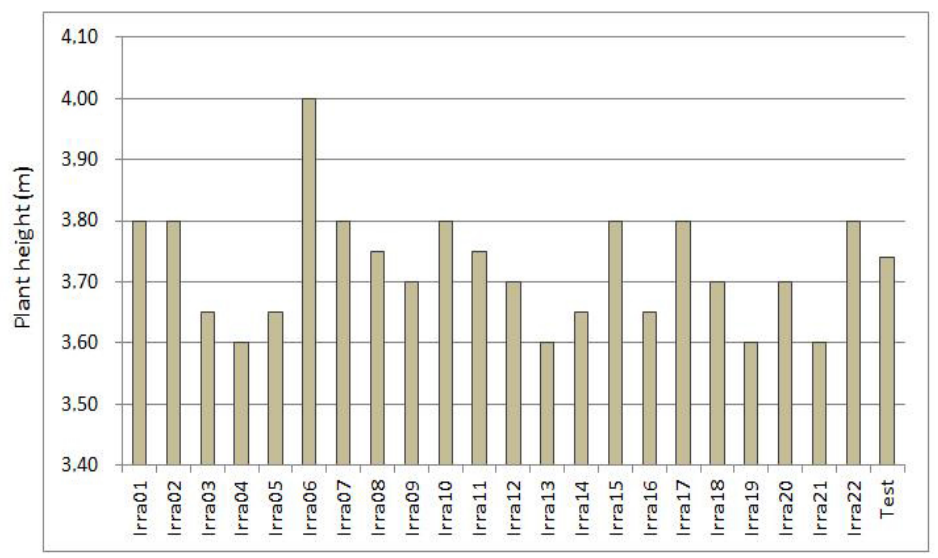

Figure 2. Distribution of selected putative mutants of Terra Maranhão plantain cultivar and mean value of the controls (Test) for the variable of plant height in meters $(\mathrm{PH})$. 
The genotypes Irra 04, Irra 13, Irra 19, and Irra 21, with heights of $3.60 \mathrm{~m}$, showed values that were below the mean value of the controls, which was $3.74 \mathrm{~m}$. Therefore, after selection, it is possible to infer that the plants selected show favorable agronomic traits, such as reduced height, and that the selection method was efficient and allowed the selection of genotypes that favored this trait. This variation was also observed in the study that was evaluated in the field and conducted by Resende (2005) in which gamma radiation at doses of 20 Gy were applied to AAB triploids (Pacovan) and 30 Gy to AAAB tetraploids (Pacovan Ken), obtaining wide genetic variability for plant size and a series of mutants for other traits.

Other selected irradiated genotypes like Irra 14 and Irra 16, with heights of $3.65 \mathrm{~m}$, seem promising. In addition to reduced height, they showed good bunch weight and a shorter period to flowering relative to the mean value of the controls; these are relevant characteristics for the next breeding stages.

A similar observation was made by López et al. (2004), who evaluated 4 banana cultivars, SH3436-L9 (AAAA), Parecido al Rey (AAA), Gran Enano (AAA), and Burro CEMSA, (AAB), under field conditions. The authors reported wide variation in the traits that were evaluated. In the first cycle, 9 clones that were derived from cultivar SH3436-L9 that was treated with 45 Gy radiation showed lower height, earlier flowering, higher number of hands per bunch, more fruits per bunch, and greater bunch weight than the control. In the third production cycle, 2 clones that were derived from the irradiation treatment of Parecido al Rey had significantly lower heights than the control plants. These results indicate that the application of gamma radiation is a promising technique to obtain short banana plants.

\section{CONCLUSIONS}

Among the putative mutants that were selected, the genotypes of Irra 14 and Irra 16 resulted in reduced height and good agronomic traits. These results confirm the potential for inducing mutations in Terra type banana plants to develop varieties with desirable agronomic traits and short height.

\section{ACKNOWLEDGMENTS}

Research supported by Conselho Nacional de Pesquisa e Desenvolvimento (CNPq). CNPp granted R.V. Reis a doctoral scholarship.

\section{REFERENCES}

Alves EJ and Lima MB (2000). Tratos Culturais. In: Banana. Produção: Aspectos Técnicos (Cordeiro ZJM, ed.). Embrapa Comunicação para Transferências de Tecnologia, Brasília, 83-91.

Bermudez-Caraballoso I, García LR, Veitía N, Torres D, et al. (2010). Mutant plantains (Musa spp.) with height reduction obtained by in vitro mutagenesis. Euphytica 176: 105-112.

Bermúdez I, Orellana PP, Pérez Ponce JP, Clavero J, et al. (2000). Improvement of the hybrid plantain clone FHIA-21 by mutagenesis in vitro. Infomusa 9: 16-19.

Cruz CD (2006). Programa GENES: Aplicativo Computacional em Genética e Estatística. UFV, Viçosa.

De Guzman EV, Del Rosario AG and Pagcaliwagan PC (1982). Production of Mutants by Irradiation of In Vitro-Cultured Tissues of Coconut and Banana and Their Mass Propagation by the Tissue Culture Technique. In: Final Research Coordination Meeting on Induced Mutations in Vegetatively Propagated Plants International Atomic Energy Agency, Vienna, 113-138. 
Donato SLR, Silva SO, Lucca Filho OA, Lima MB, et al. (2006). Correlações entre caracteres da planta e do cacho em bananeira (Musa spp.). Cienc. Agrotecnol. 30: 21-30.

FAO (2013). Food and Agriculture Organization of the United Nations. Available at [http://faostat3.fao.org/faostatgateway/go/to/browse/Q/QC/E]. Accessed July 5, 2013.

IBGE (2013). Instituto Brasileiro de Geografia e Estatítisca. Available at [http://www.ibge.gov.br/home/estatistica/ indicadores/agropecuaria/lspa/lspa_201304.pdf] Accessed July 7, 2013.

Jamaluddin SH (1994). Mutation Breeding of Banana in Malaysia. In: The Improvement and Testing of Musa: A Global Workshop (Jones DR, ed.). International Network for the Improvement of Banana and Plantain, Montpellier, 228-232.

Kosman E and Leonard KJ (2005). Similarity coefficients for molecular markers in studies of genetic relationships between individuals for haploid, diploid, and polyploid species. Mol. Ecol. 14: 415-424.

Ledo AS, Ledo FJ and Silva SO (1997). Avaliação de Cultivares de Banana em Rio Branco-Acre. Boletim de Pesquisa 15. Rio Branco.

López J, Strosse H, Ventura JC and Sánchez R (2004). Field Evaluation of Potential Mutants Obtained After Gamma Irradiation of Banana and Plantain (Musa spp.) Shoot-tip and Embryogenic Cell Cultures. In: Banana Improvement: Cellular, Molecular Biology, and Induced Mutations (Jain SM and Swennen R, eds.). Science Publishers Inc., Enfield, 87-96.

Murashige T and Skoog F (1962). A revised medium for rapid growth and bio assays with tobacco tissue cultures. Physiol. Plantarum 15: 473-497.

Niwa $\mathrm{O}$ (2006). Indirect mechanisms of genomic instability and the biological significance of mutations at tandem repeat loci. Mutat. Res. 598: 61-72.

Pestana RKN, Amorim EP, Silva SO and Neto AT (2010). Irradiação gama para mutagênese in vitro em bananeira 'Terra Maranhão'. Pesq. Agropec. Bras. 45: 1328-1330.

Pestana R, Amorim E, Ferreira C, Amorim VBO, et al. (2011). Agronomic and molecular characterization of gamma ray induced banana (Musa sp.) mutants using a multivariate statistical algorithm. Euphytica 178: 151-158.

R Development Core Team (2010). R: A Language and Environment for Statistical Computing. R Foundation for Statistical Computing, Vienna.

Resende JCF (2005). Melhoramento da Bananeira (Musa spp.) Utilizando Indução de Mutação com Raios Gama e Variação Somaclonal para a Redução da Altura de Plantas. Doctoral thesis, Centro de Energia Nuclear na Agricultura, Universidade de São Paulo, Piracicaba.

Shepherd K (1987). Banana breeding: past and present. Acta Hort. 196: 37-44.

Silva SO, Flores JCO and Lima Neto FP (2002). Avaliação de cultivares e híbridos de bananeira em quatro ciclos de produção. Pesq. Agropec. Bras. 37: 1567-1574.

Singh D (1981). The relative importance of characters affecting genetic divergence. Indian J. Genet. Plant Breed. 41: 237-245.

Tamura K, Dudley J, Nei M and Kumar S (2007). MEGA4: Molecular Evolutionary Genetics Analysis (MEGA) software version 4.0. Mol. Biol. Evol. 24: 1596-1599.

Vaz Patto MC, Satovic Z, Pêgo S and Fevereiro P (2004). Assessing the genetic diversity of Portuguese maize germplasm using microsatellite markers. Euphytica 137: 63-72. 